Arab Univ. J. Agric. Sci., Ain Shams Univ., Cairo, Egypt

28(4), 1117-1130, 2020

Website: http://ajs.journals.ekb.eg

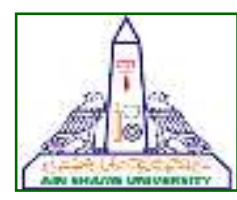

1117

\title{
Antibacterial Bioactivity of Some Lactic Acid Bacteria Isolated from Various Egyptian Products
}

\section{Amir M Kamel ${ }^{1 *}$, Azhar A El-Sayed ${ }^{2}$, Bothaina M Youssef ${ }^{1}$, Shimaa A Amin²}

1- Radiation Microbiology Dept, National Center for Radiation Research and Technology, Egyptian Atomic Energy Authority, Egypt

2- Agricultural Microbiology Dept, Fac of Agric, Ain Shams Univ, P.O. Box 68, Hadayek Shoubra 11241, Cairo, Egypt

${ }^{*}$ Corresponding author: AmirKamel2005@yahoo.com

Received 10 August, 2020

Accepted 19 November, 2020

\section{Abstract}

The current research aimed to isolate and screening of antibacterial bioactive lactic acid bacteria (LAB) from different foods such as raw milk, dairy products and fermented meat and evaluate their potential for production of antibacterial substances, namely bacteriocins. Ten samples were collected from different market foods, examined and used for LAB isolation on MRS medium. A total of 71 bacterial isolates were selected based on some variation properties, such as color, shape, size and oxygen requirements. These isolates were confirmed as lactic acid bacteria based on their microscopic observation and chemical properties, i.e. catalase negative and acid producing from glucose fermentation. All selected isolates were grown on MRS medium at $37^{\circ} \mathrm{C}$ for $48 \mathrm{~h}$, and compared to identified LAB strains, i.e. Lactococcus lactis, Streptococcus thermophilus, Befidobacterium sp, Lactobacillus casi, $L b$ rhamnosus, $L b$. acidophilus, $L b$. helveticus and $L b$. plantarum. Isolates and strains were surveyed for bacteriocin production as inhibitory activity test. Partial purification of bacteriocin was carried out by salt precipitation method; this method was done by ammonium sulphate $40-60 \%$ saturation and centrifuged at $9500 \mathrm{rpm}$ for 20 minutes at $4^{\circ} \mathrm{C}$. Some of microbial indicator strains found to test by inhibitory biological activity substance (partial purification of bacteriocin) produced by lactic acid cultures. Indicator strains such as staphylococcus aureus, Listeria monocytogenes and others were grown by nutrient agar at $37^{\circ} \mathrm{C}$ for $24 \mathrm{~h}$. An inhibitory activity test was executed by paper diffusion method. The inhibition effect was examined by form clear inhibition zone around indicator strains. Twenty-eight isolates and the $8 \mathrm{LAB}$ strains showed bioactivities against the tested pathogens. Gram positive indicator bacteria were found to be the most sensitive to inhibitory substances produced by LAB culture as compared to gram negative indicator strains. Staphylococcus aureus was exhibited the highest sensitivity to it. The highest bacteriocins activities were produced by strain Lactobacillus rhamnosus while $\mathrm{R} 5$ and $\mathrm{S} 6$ from $\mathrm{LAB}$ isolates. They were shown broad spectrum against gram positive and gram-negative pathogenic bacteria. Diameters of inhibition zone refer to degree of sensitive between indicator strains and bacteriocin activity.

Keywords: Lactic acid bacteria, MRS medium, antibacterial agent, Bacteriocin, Paper diffusion method.

\section{Introduction}

Lactic acid bacteria (LAB) are Gram-positive, bacilli, cocci, or poly-form shaped, in pairs, tetrad or in chain, catalase-negative, devoid cytochrome, non-respiring but aero-tolerant, and the optimum growth is in micro-aerophilic or anaerobic condition, with optimum $\mathrm{pH}$ between 5.5 and 6 (Sadishkumar and Jeevaratnam 2016). They play very important role in food fermentation and preservation, they are generally recognized as safe (GRAS) bacteria and 
either as normal microflora or used as starter cultures in some food products under controlled conditions (Mirnejad et al 2013). Some species are Probiotic, this term remain promoting good human health and safe for human consumption. Probiotics refer to microorganisms that are consumed as a part of nutrition (directly or indirectly), producing useful effect and refining the microbial balance in gastrointestinal tract for human and animal (Quinto et al 2014, Nallala et al 2016).

Lactic acid bacteria (LAB) are classified based on cellular morphology, mode of glucose fermentation, utilization of sugar and rang of temperature growth. They are classified in phylum Firmicutes, class Bacilli and order Lactobacillus (Quinto et al 2014). Based on fermentation end products from organic acid, $L A B$ are categorized into two groups, homo-fermentative group, where lactic acid is the main product, and hetero-fermentative group produce lactic acid, acetic acid, alcohol and carbon dioxide (Mokoena et al 2016).

$\mathrm{LAB}$ produces various antimicrobial substances such as organic acids, diacetyl, carbon dioxide, hydrogen peroxide and bacteriocins (Puniya et al 2012).

Bacteriocins are antimicrobial peptides produced by some gram-negative and gram-positive bacteria including members of Lactic acid bacteria, active against similar or closely related bacterial species. They are primary metabolite and ribosomally synthesized (Belicova et al 2013). They are like antibiotic substance which are encoded often in the plasmids but sometimes encoded in chromosomes or transposons. They are extracellular biological active peptides or peptide complexes that are bacteristatic or bactericidal due to strategy action of the bacteriocin and the host autolysin strain (Kleanthous 2010).

The first discovered bacteriocin was Colicine in 1952 from E. coli by Andre Gratia and his work group, and subsequently a lot of bacteriocins have been successively identified (Settann and Corsetti 2008).

Bacteriocins have two type, first type has narrow spectrum whereas its activity only against similar species while the second type, less common, has broad spectrum activity. Nisin which produces by Lactococcus lactis subsp lactis is the best example of second type (Mills et al 2011).

Bacteriocins of LAB are classified by Jeevuratnam et al (2005) and Murua et al (2013) into four classes.
Class I: (Lantibiotics) they are small active peptides, contain unusually amino acids and heat stable. Class II: they are small active peptide, heat stable but its amino acids are usually unmodified. Class III: they are large active peptides, heat labile proteins. Class IV: (circular peptides) they are large protein complexes with other moieties, lipids or carbohydrate required for activity.

Bacteriocins target energized membrane to lack the proton motive force (PMF) and then inhibit amino acids transport. PMF is very important in the cell membrane in several processes, such as the accumulation of ions and ATP synthesis (Guilhelmelli et al 2013). Negatively-charged phosphate groups on target cell membranes play important role in forming initial binding with the positively-charged bacteriocin molecules, thus depleting the transmembrane potential and $\mathrm{pH}$ gradient. Bacteriocins are hydrophobic peptides inserts into membrane, forming pores through common two strategies, barrel-stave or wedge (Snyder and Worobo 2013).

Bacteriocins are small cationic hydrophobic molecules of about 30-60 amino acids, forming amphiphilic helices. LAB strains protect themselves from their produced bacteriocins by a specific immunity protein, which encoded in same of the bacteriocin operon (Parada et al 2007).

Lan I and Lan EFG protein specific immunity protein are preventing pore formation by pushing back the bacteriocin molecules which are inserted into the cytoplasmic membrane, therefore the bacteriocin concentration in the membrane is kept under control (Zacharof and Lovit 2012).

Bacteriocins are suitable as biopreservatives of food products since they are inactivated by protyolitic enzymes when consumed in gastrointestinal tract. In addition, they are also non-toxic, non-immunogenic, inactive against eukaryotic cells, resistant to high temperature, active at low $\mathrm{pH}$ and have broad spectrum activity against some food-borne and spoilage microorganisms (Nath et al 2014).

The application of bacteriocin can increase shelf-life of many foods. It is considered as an extra protection during temperature treatment; decreasing the risk of food-borne pathogens through the food handling, and reducing the need for heat treatments and chemical preservatives in food products, without reducing food safety (Güllüce et al 2013).

Although several bacteriocins have been discovered, only Nisin has been used as commercial food preservative widely in about fifty countries. The limited utilization of bacteriocins as preservatives in 
the commercial industry is mainly derived from narrow spectrum inhibitory activity and the high cost of production (Fahim et al 2016).

In this paper we report on isolation and screening antibacterial bioactivities $L A B$ isolated from various Egyptian foods against gram-positive and gram-negative pathogenic bacteria.

\section{Materials and Methods}

\subsection{Sampling}

Certain sources were tapped for isolation of lactic acid bacteria, composed of ten samples of raw milk, dairy products, pickles and fermented meat, procured from different local markets, and were immediately transferred in cool boxes to the microbiology laboratory and kept refrigerated $\left(\approx 4^{\circ} \mathrm{C}\right)$ until used for isolation.

Sample's physical and chemical characteristics, including color, taste, texture, $\mathrm{pH}$, electrical conductivity and TDS, were examined.

\subsection{Strains}

All strains of LAB, (Lactococcus (Lc) lactis, Streptococcus (St) thermophilus, Befidobacterium $\mathrm{sp}$, Lactobacillus $(L b)$ casi, $L b$ rhamnosus, $L b$. acidophilus, Lb. helveticus and Lb. plantarum). And indicator pathogenic strains (Escherichia coli, Salmonella typhi, Shigella sp, Listeria monocytogenes, Staphylococcus aureus, Bacillus cereus, and $B$. subtilis), were obtained from Cairo Microbiological Resources Center (MIRCEN), Faculty of Agriculture, Ain Shams University.

\subsection{Media}

MRS medium was used to isolate and propagate LAB strains (Mohammed et al 2016) and Pathogenic strains were grown on nutrient medium (Rashmi et al 2017).

\subsection{Isolation of LAB}

For isolation of $L A B$, ten $\mathrm{ml}$ (or $10 \mathrm{~g}$, where appropriate) of each sample was homogenized with 90 $\mathrm{ml} \mathrm{MRS}$ broth medium and incubated at $37^{\circ} \mathrm{C}$ for 48 $h$ for enrichment the total LAB (Somashekaraiah et al 2019). Then each sample was serially diluted to $10^{-8}$, using sterile solution (Khalil and Anwar, 2016). One $\mathrm{ml}$ from each dilution of $10^{-5}$ to $10^{-8}$ was poured onto MRS agar plates, then overlaid with MRS soft agar $(0.75 \%$ agar $)$ and incubated after solidification at $37^{\circ} \mathrm{C}$ for $48 \mathrm{~h}$. After appearance of separated visible growth in the MRS agar plates, well-isolated colonies with distinct cultural differences, such as differences in color, shape, size and had microaerophilic or anaerobic, were carefully picked from each plate and transferred to MRS broth (Nikita and Hemangi 2012). Each isolated colony was sub-cultured for purification.

\subsection{Conformation tests of LAB}

Overnight cultures of $L A B$ pure isolates were examined by Gram staining and microscopically for morphological shape; Catalase test was carried out by adding few drops up to $1 \mathrm{ml}$ of $3 \%$ hydrogen peroxide to clean test tube containing $1 \mathrm{ml}$ overnight cultures within 5-10 seconds (Sangita et al 2013), and acid production from glucose fermentation was also tested (Mahantesh et al 2010). The isolates conforming to the notable characteristics of $L A B$ (viz. Gram-positive, catalase-negative, rods or cocci and glucose fermentation-acid production) were selected for antagonistic bioactivity against chosen indicator pathogenic bacteria.

\subsection{Glucose fermentation test}

Fermentation test was performed in MRS broth medium containing $1 \%$ glucose $(\mathrm{w} / \mathrm{v})$ and bromothymol blue $0.1 \%$ as $\mathrm{pH}$ indicator and incubation at $37^{\circ} \mathrm{C}$ for $48 \mathrm{~h}$ without shaking (Khalil and Anwar 2016).

\subsection{Preparation of the cell-free supernatants}

Inocula were prepared as follow: $0.1 \mathrm{~m}$ of each overnight LAB culture was transferred to $10 \mathrm{ml}$ of MRS broth medium and incubated at $37^{\circ} \mathrm{C}$ for $48 \mathrm{~h}$ without shaking (Al-Zahrani and Al-Zahrani 2006).

Extraction of bioactive substances was carried out according to the method described by Gautam and Sharma (2009) with minor modifications. The culture of $L A B$ was centrifuged at $6000 \mathrm{rpm}$ for 15 minutes at $4^{\circ} \mathrm{C}$, and pellets were decanted while the supernatant was designated as the crude extract of bacteriocin. The crude extract $\mathrm{pH}$ was adjusted to 6.5 using $\mathrm{NaOH}$ to avoid the effects of organic acids and keep away from the isoelectric point, and then heated at $60-70^{\circ} \mathrm{C}$ for 10 minutes to inactivate any present enzymes, especially proteases (Simova et al 2009). 


\subsection{Partial purification of bacteriocin}

For detection of antibacterial bioactivity of each isolate, bacteriocin was partially purified by salt saturation strategy. Solid ammonium sulphate was slowly added to the crude extract to reach $60-70 \%$ saturation and held overnight at $4^{\circ} \mathrm{C}$ without stirring. The mixture was centrifuged at $9500 \mathrm{rpm}$ for 20 minutes at $4^{\circ} \mathrm{C}$, and the pellets were re-suspended in $1 \mathrm{ml}$ phosphate buffer pH 6 (Dhewa 2012).

\subsection{Determination of antimicrobial bioactivity}

Antimicrobial activity of bacteriocin was tested by disc diffusion method against gram-positive and gram-negative food-borne pathogens, which listed above (Savadogo et al 2004). $100 \mu$ of the partially purified bacteriocin were placed on a filter paper disc of $5 \mathrm{~mm}$ in diameter. All the tests were performed on nutrient agar plates inoculated with $0.5 \%$ overnight culture of pathogenic bacteria (Rashmi et al 2017) and left for $2 \mathrm{~h}$ at room temperature to allow suitable diffusion of the bacteriocin through the medium. Plates were incubated at $37^{\circ} \mathrm{C}$ for $24 \mathrm{~h}$. At the end of incubation time, diameters of inhibition zones were measured (Daniel et al 2016).

\section{Results and Discussion}

\subsection{Samples' Characteristics}

Examined characteristics of the samples are listed in Table 1. Samples showed different physical and chemical properties, colors were found to be white for raw milk and dairy products but Luncheon and Pickles were red. Mostly tastes were sour, whereas textures were Liquid, soft or solid. The chemical properties as sample's $\mathrm{pH}$ values were between neutral to acidic. All samples had natural properties for each product and not expired so that they were valid for human consumption.

\subsection{Isolation of LAB}

This experiment aimed to isolate a number of lactic acid bacteria with antimicrobial bioactivity agent. All isolates were grown on MRS medium and a total of 71 isolates were recovered from different sources, (raw milk, dairy products, pickles and meat fermented). Products used as sources of LAB isolates are as follow:

Local yoghurt $(\mathrm{Y}): 6$ isolates, Luncheon $(\mathrm{B}): 9$ isolates, Raw Milk (M): 11 isolates, Commercial sweeten yoghurt $(H)$ : 5 isolates, Commercial yoghurt (R): 7 isolates, pickles (L): 11 isolates, White cheese(C): 6 isolates, Sour milk(S): 6 isolates, Processed cheese $(\mathrm{N})$ : 5 isolates and Fresh cheese (D): 5 isolates.

Table 1. Physical and chemical properties of samples

\begin{tabular}{|c|c|c|c|c|c|c|c|}
\hline Samples & Code & Color & taste & texture & pH & $\begin{array}{c}\text { E.C } \\
\text { mS/cm }\end{array}$ & $\begin{array}{c}\text { TDS } \\
\text { ppm }\end{array}$ \\
\hline Local yoghurt & Y & White & Sour & soft & 3.77 & 1.22 & $7.8 \times 10^{3}$ \\
\hline Luncheon & B & Red & Slightly sour & solid & 5.7 & 4.82 & $3.0 \times 10^{4}$ \\
\hline Raw milk & M & White & // & liquid & 6.7 & 3.54 & $2.26 \times 10^{3}$ \\
\hline $\begin{array}{c}\text { Commercial sweeten } \\
\text { yoghurt }\end{array}$ & H & White & Sweeten & soft & 4.06 & 0.79 & $5.0 \times 10^{3}$ \\
\hline Commercial yoghurt & R & White & Sour & soft & 4.08 & 1.11 & $7.1 \times 10^{3}$ \\
\hline Pickles & L & Red & Sharp & liquid & 3.4 & 63.2 & $4.9 \times 10^{4}$ \\
\hline $\begin{array}{c}\text { White cheese } \\
\text { C }\end{array}$ & White & Slightly sour & Liquid+ & 4.14 & 37.5 & $2.4 \times 10^{4}$ \\
\hline Sour milk & S & White & Extremely Sour & Semi liquid & 3.91 & 6.2 & $3.9 \times 10^{3}$ \\
\hline Processed cheese & N & White & Slightly sour & soft & 5.5 & 12 & $1.3 \times 10^{4}$ \\
\hline Fresh cheese & D & White & Sour & soft & 4.8 & 49 & $3.6 \times 10^{4}$ \\
\hline
\end{tabular}



Isolated from Various Egyptian Products

\subsection{Conformation tests of Lactic acid bacteria isolates}

All isolates were found to be Gram-positive and catalase negative, their shapes under the light microscope were bacilli, cocci or pleomorphic. The color of the medium changed from blue to yellow due to the formation of acids as results of glucose fermentation. Amount of acid production was compared between LAB isolates and strains Table 2. These are characteristics of $L A B$; these results were found to be similar to those reported by Khalil and Anwar (2016).

Table 2. Conformation tests of Lactic acid bacteria isolates and strains

\begin{tabular}{|c|c|c|c|c|c|c|c|}
\hline Isolates & $\begin{array}{c}\text { Morphology } \\
\text { shape }\end{array}$ & $\begin{array}{c}\text { Change } \\
\text { color }\end{array}$ & $\mathrm{pH}$ & Isolates & $\begin{array}{c}\text { Morphology } \\
\text { shape }\end{array}$ & $\begin{array}{l}\text { Change } \\
\text { color }\end{array}$ & $\mathrm{pH}$ \\
\hline St. thermophilus & cocci & +++ & 4.6 & $\mathrm{C} 2$ & Cocci & +++ & 4.38 \\
\hline Lc. lactis & cocci & +++ & 4.39 & C3 & Cocci & ++ & 5.05 \\
\hline Lb. acidophilus & Bacilli & +++ & 4.53 & $\mathrm{C} 4$ & Cocci & +++ & 4.63 \\
\hline Lb. casi & Bacilli & +++ & 4.3 & C5 & Bacilli & +++ & 4.03 \\
\hline Lb. rhamnosus & Bacilli & +++ & 4.35 & C6 & Cocci & +++ & 4.15 \\
\hline Lb. Plantarum & Bacilli & +++ & 4.5 & $\mathrm{R} 1$ & Cocci & +++ & 4.66 \\
\hline Lb. helveticus & Bacilli & ++ & 5.05 & $\mathrm{R} 2$ & Cocci & ++ & 4.81 \\
\hline Befidobacterium sp & Pleomorphic & +++ & 4.42 & R3 & Cocci & +++ & 4.31 \\
\hline $\mathrm{Y} 1$ & Cocci & +++ & 4.66 & R4 & Bacilli & ++ & 4.9 \\
\hline $\mathrm{Y} 2$ & Bacilli & + & 5.56 & R5 & bacilli & + & 5.3 \\
\hline Y3 & Bacilli & +++ & 4.49 & R6 & bacilli & ++ & 4.94 \\
\hline Y4 & cocci & +++ & 4.12 & R7 & Bacilli & + & 5.32 \\
\hline Y5 & Bacilli & +++ & 4.4 & L1 & Bacilli & +++ & 4.02 \\
\hline Y6 & bacilli & +++ & 4.3 & L2 & cocci & +++ & 4.15 \\
\hline B1 & Bacilli & + & 5.7 & L3 & Bacilli & +++ & 4.29 \\
\hline B2 & Bacilli & ++ & 5.2 & L4 & cocci & +++ & 4.01 \\
\hline B3 & Bacilli & +++ & 4.17 & $\mathrm{~L} 5$ & Bacilli & +++ & 4.29 \\
\hline B4 & Pleomorphic & +++ & 4.27 & L6 & cocci & +++ & 3.89 \\
\hline B5 & cocci & +++ & 4.51 & $\mathrm{~L} 7$ & Bacilli & +++ & 4.25 \\
\hline B6 & Bacilli & +++ & 4.13 & L8 & Cocci & +++ & 4.00 \\
\hline B7 & Bacilli & ++ & 4.85 & L9 & Bacilli & ++ & 4.91 \\
\hline B8 & cocci & + & 5.6 & L10 & Bacilli & +++ & 4.25 \\
\hline B9 & Pleomorphic & +++ & 4.36 & L11 & cocci & +++ & 4.62 \\
\hline M1 & cocci & +++ & 4.39 & S1 & Bacilli & +++ & 4.38 \\
\hline M2 & cocci & +++ & 4.31 & S2 & Cocci & +++ & 4.35 \\
\hline M3 & Bacilli & +++ & 4.65 & S3 & Bacilli & ++ & 4.72 \\
\hline M4 & Bacilli & +++ & 3.94 & S4 & Bacilli & +++ & 4.52 \\
\hline M5 & Pleomorphic & +++ & 4.41 & S5 & Cocci & +++ & 4.55 \\
\hline M6 & Bacilli & +++ & 4.52 & S6 & Pleomorphic & +++ & 4.36 \\
\hline M7 & Bacilli & + & 5.75 & $\mathrm{~N} 1$ & Cocci & ++ & 5.02 \\
\hline M8 & cocci & +++ & 4.31 & $\mathrm{~N} 2$ & Cocci & ++ & 5.11 \\
\hline M9 & Pleomorphic & +++ & 4.44 & N3 & Bacilli & + & 5.75 \\
\hline M10 & Bacilli & + & 5.65 & N4 & Bacilli & + & 5.59 \\
\hline M11 & cocci & +++ & 4.01 & N5 & Bacilli & + & 5.81 \\
\hline $\mathrm{H} 1$ & Cocci & +++ & 4.41 & D1 & Bacilli & +++ & 4.04 \\
\hline $\mathrm{H} 2$ & Cocci & + & 5.52 & $\mathrm{D} 2$ & Pleomorphic & +++ & 4.29 \\
\hline $\mathrm{H} 3$ & Bacilli & + & 5.67 & D3 & Cocci & +++ & 4.51 \\
\hline $\mathrm{H} 4$ & Cocci & +++ & 4.18 & D4 & Bacilli & + & 5.7 \\
\hline $\mathrm{H} 5$ & Bacilli & +++ & 4.22 & D5 & cocci & +++ & 3.9 \\
\hline $\mathrm{C} 1$ & Bacilli & + & 5.34 & & & & \\
\hline
\end{tabular}

Change color of $\mathrm{pH}$ indicator: +++ extremely, ++ moderate and + slightly 


\subsection{Bacteriocin purification}

\subsubsection{Characterization of the crude extract of bacteriocin}

The bacteriocins of $L A B$ strains and isolates were preceded for the extraction. $L A B$ cultures were centrifuged and cell free supernatants were collected to potential display antimicrobial bioactivity. LAB secreted many substances that may, including Bacteriocins, hydrogen peroxide, enzymes, lactic acid, and aldehydes. The antimicrobial activity due to these substances must be eliminated before detection of antimicrobial bioactivity. Therefore, the cell free supernatants were subjected to the following treatments: adjusting the $\mathrm{pH}=6$ to avoid acidity effect of lactic acid production, heating at $60-70^{\circ} \mathrm{C}$ for 10 minutes to exclude effect of enzymes then addition of ammonium sulphate to precipitated partially purified bacteriocins. Ammonium sulphate has an important role in protein precipitation; the water molecules become attracted to the salt because it's higher charge, and thus it decreases bacteriocin solubility in water, and thus can be easily removed (Gautam and Sharma 2009).

\subsubsection{Characterization of partially purified bacte- riocin}

The partially purified bacteriocin was precipitated from cell free supernatant by $60-70 \%$ ammonium sulfate. Partially purified bacteriocin was precipitated as a pellet after second centrifugation. The pellet showed complete insolubility in Potassium phosphate buffer ( $\mathrm{pH}$ 7.0). This solution was used in following experiments.

\subsection{Antibacterial spectrum of bacteriocins}

Antagonistic bioactivity of the LAB isolates and strains against indicator pathogenic bacteria was carried out using the partially purified bacteriocin. Inhibition test of target organisms was conducted by disc diffusion method.
All LAB strains and twenty-eight isolate produced antimicrobial bioactive substances. Results in Fig 1 clearly show that Percentage of twentyeight LAB isolates from Various Egyptian Products exhibited antibacterial activity of partially purified bacteriocin against microbial indicator strains.

Raw milk contained the highest percentage of antimicrobial bioactivity LAB isolates (22\%), followed by Luncheon (14\%) and sour milk (14\%). while white cheese had the least percentage (4\%) of total bioactivity LAB isolates.

Bacteriocin activities, as diameter of clear inhibition zone, of $\mathrm{LAB}$ strains and isolates against the indicator strains are shown in Figs 2, 3, 4 and 5, these diameters were recorded after cut down $5 \mathrm{~mm}$ which the diameter of paper disc, results were in agreement with those obtained by Mohammed et al (2016). Some isolates showed inhibitory bioactivity against only gram-positive pathogenic bacteria, others had inhibitory bioactivity against both of grampositive and gram-negative bacteria.

Most of the inhibitory strains and isolates showed inhibition zones after incubated for 18-24h and several inhibition zones demonstrated during 48-72h incubation, this may be due to the development of resistance in Indicator microbial strains.

Data presented in Figs 2 and $\mathbf{3}$ show evaluation of the bacteriocin as bioactive agent of LAB strains by disc diffusion method (diameter of inhibition zone), against gram-negative and gram-positive pathogenic bacteria, respectively. These data illustrate that streptococcus thermophilus, Lactococcus lactis, Lactobacillus casi and Lactobacillus rhamnosus were highly active against the tested indicator bacteria, while Lactobacillus helveticus produced slight bioactive substance against gram-positive pathogens and no bioactivity reaction against gramnegative pathogens.

Bioactivities of $L A B$ isolates against the pathogenic bacteria are presented in Figs 4-9. Isolates which did not give any activity, i.e. no inhibition zone against any indicator pathogen, are not included in the charts.

Isolates demonstrating highly bioactivity against gram-negative and gram-positive indicator pathogens were B1, Y4, M8, M10, C1, R5, S4, S6, N4 and N5. While R5 and S6 were the isolates with the highest bioactivities against indicator pathogens. 


\section{Percentage of antimicrobial bioactive LAB isolates}

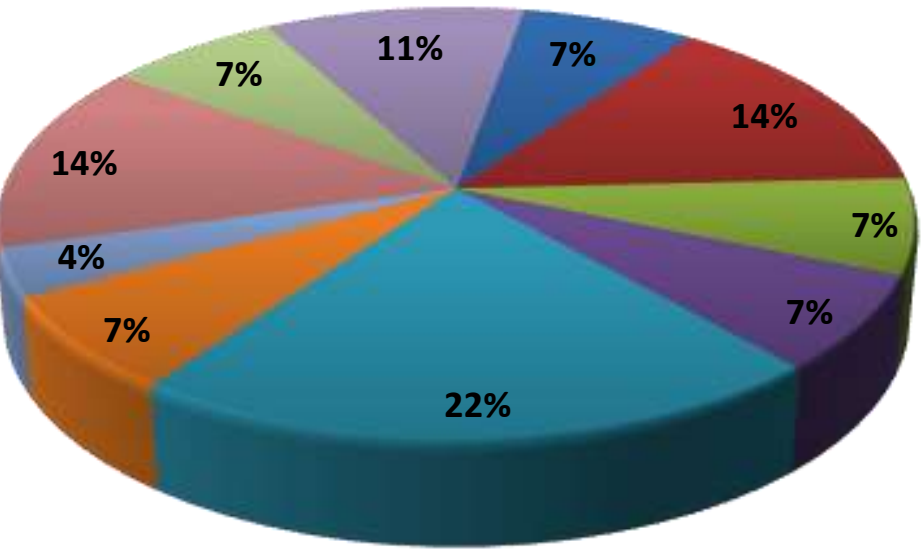

Gocal yoghurt

Lunchone

تCommercial yoghurt

Commercial sweeten yoghurt

GRaw milk

Mickles

White cheese

GSour milk

TProcessed cheese

Fig 1. Percentage of antibacterial bioactive $L A B$ isolates obtained from various foods

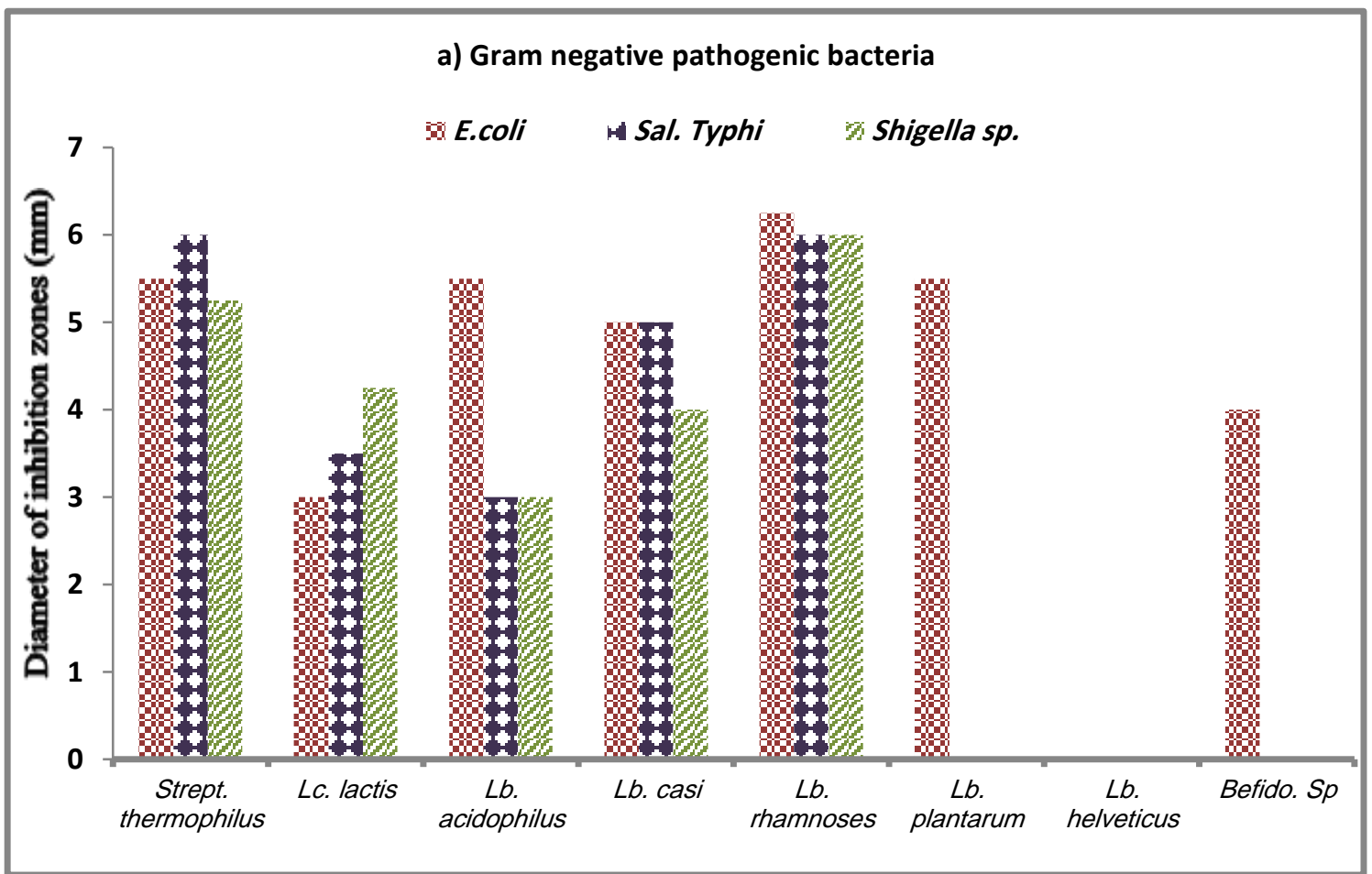

Fig 2. Antibacterial bioactivity (diameter of clear zone) of LAB strains against gram-negative pathogenic bacteria 


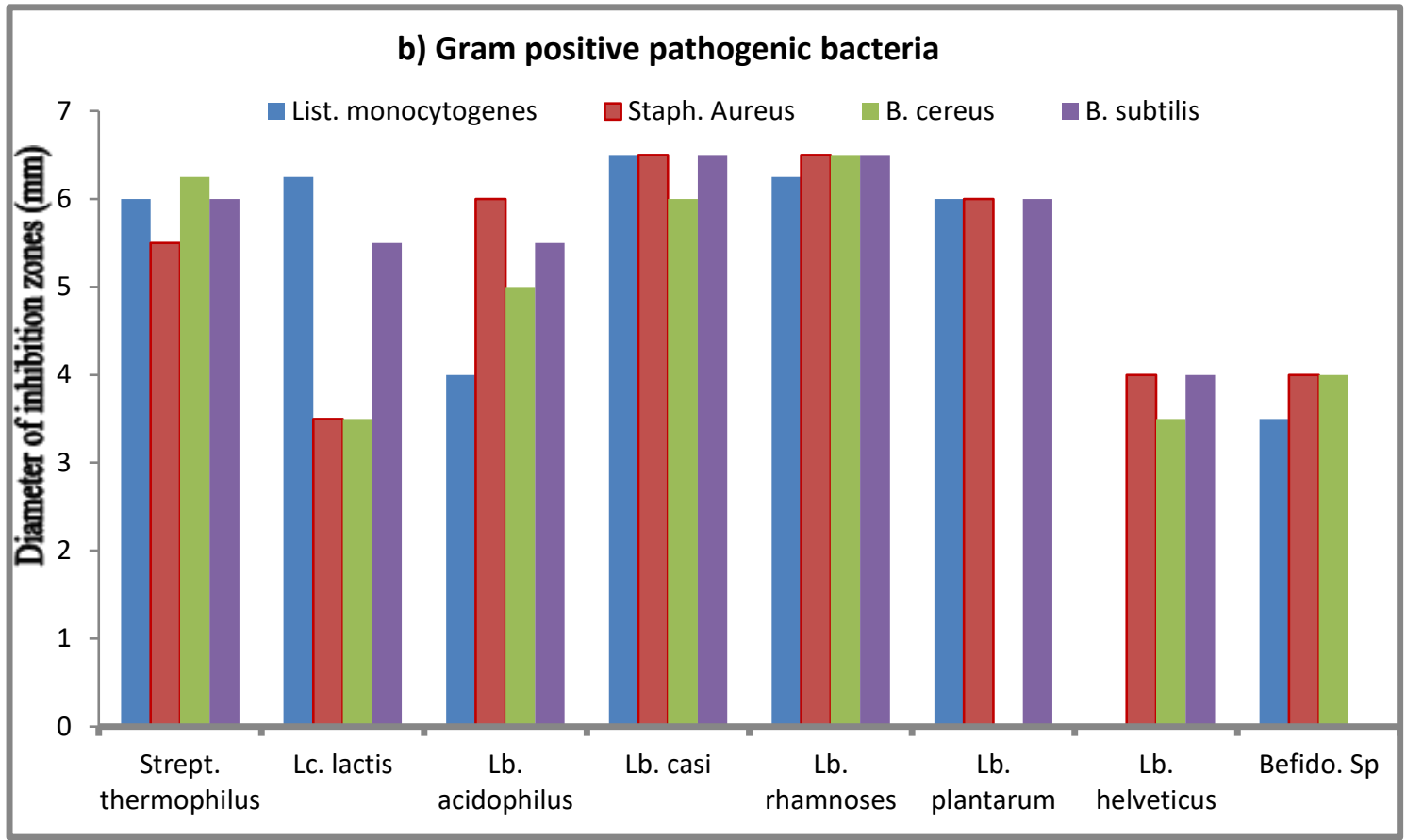

Fig 3. Antibacterial bioactivity (diameter of clear zone) of $L A B$ strains against gram-positive pathogenic bacteria

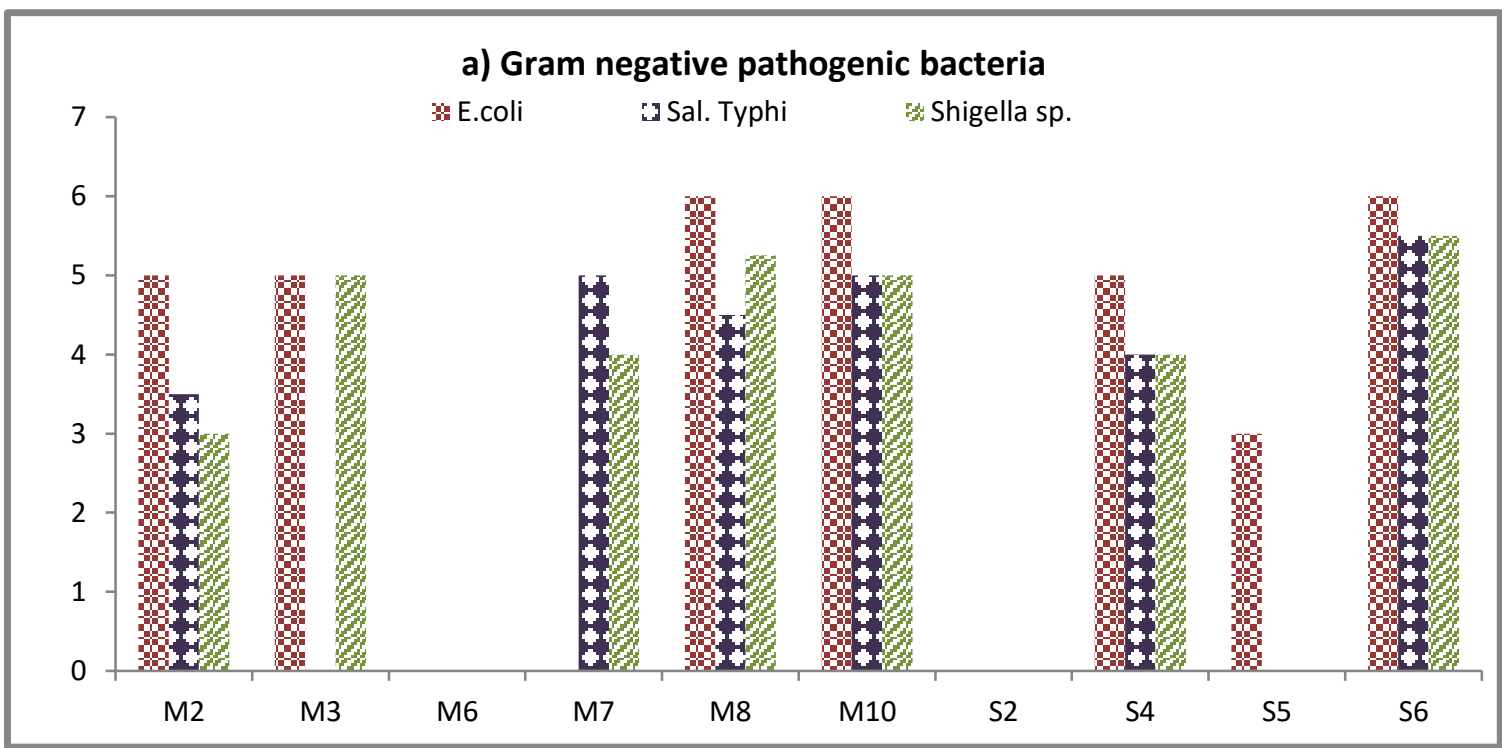

Fig 4. Antibacterial bioactivity (diameter of clear zone) of LAB isolated from raw milk (M) and sour milk (S) against gram-negative pathogenic bacteria 


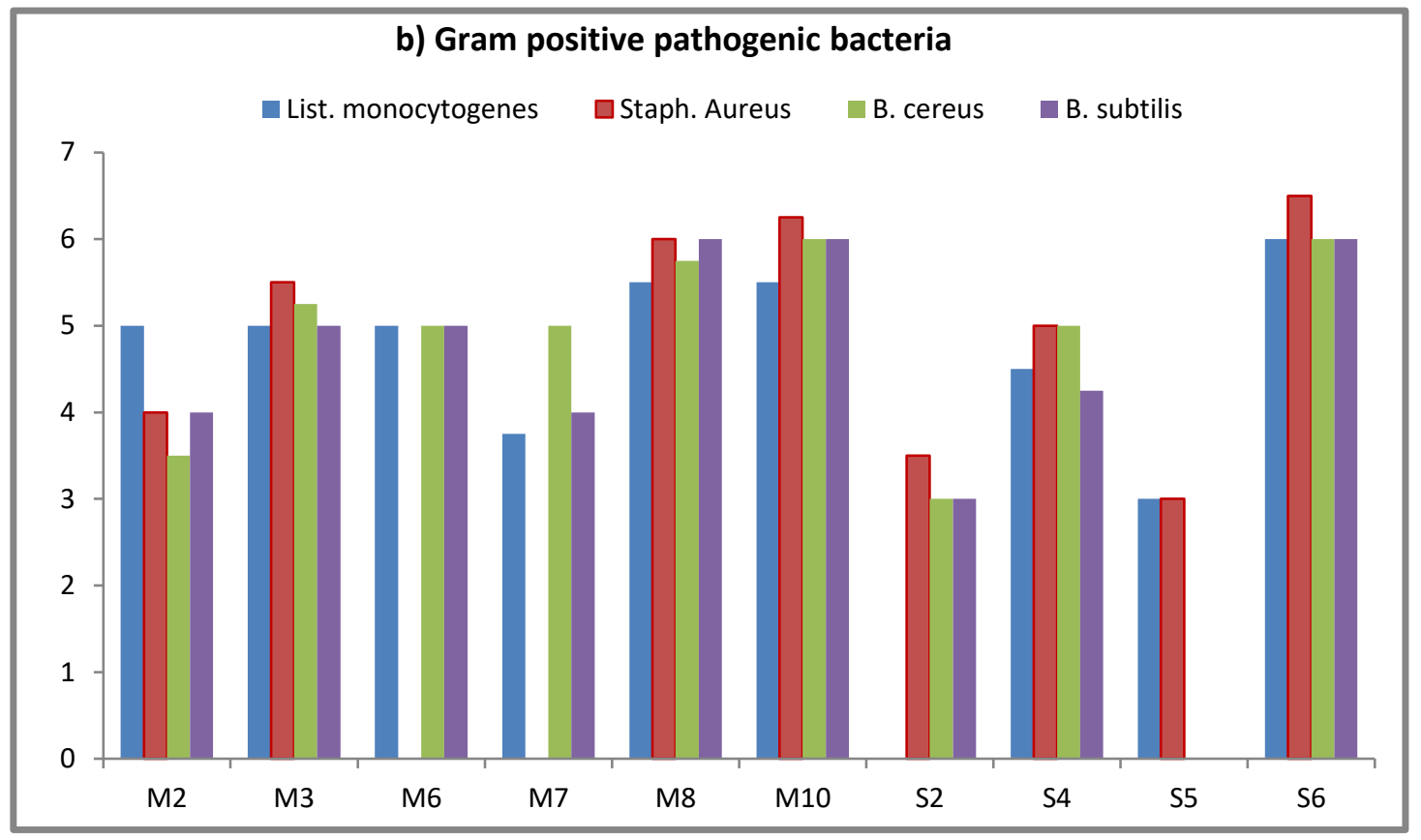

Fig 5. Antibacterial bioactivity (diameter of clear zone) of LAB isolated from raw milk (M) and sour milk (S) against gram-positive pathogenic bacteria.

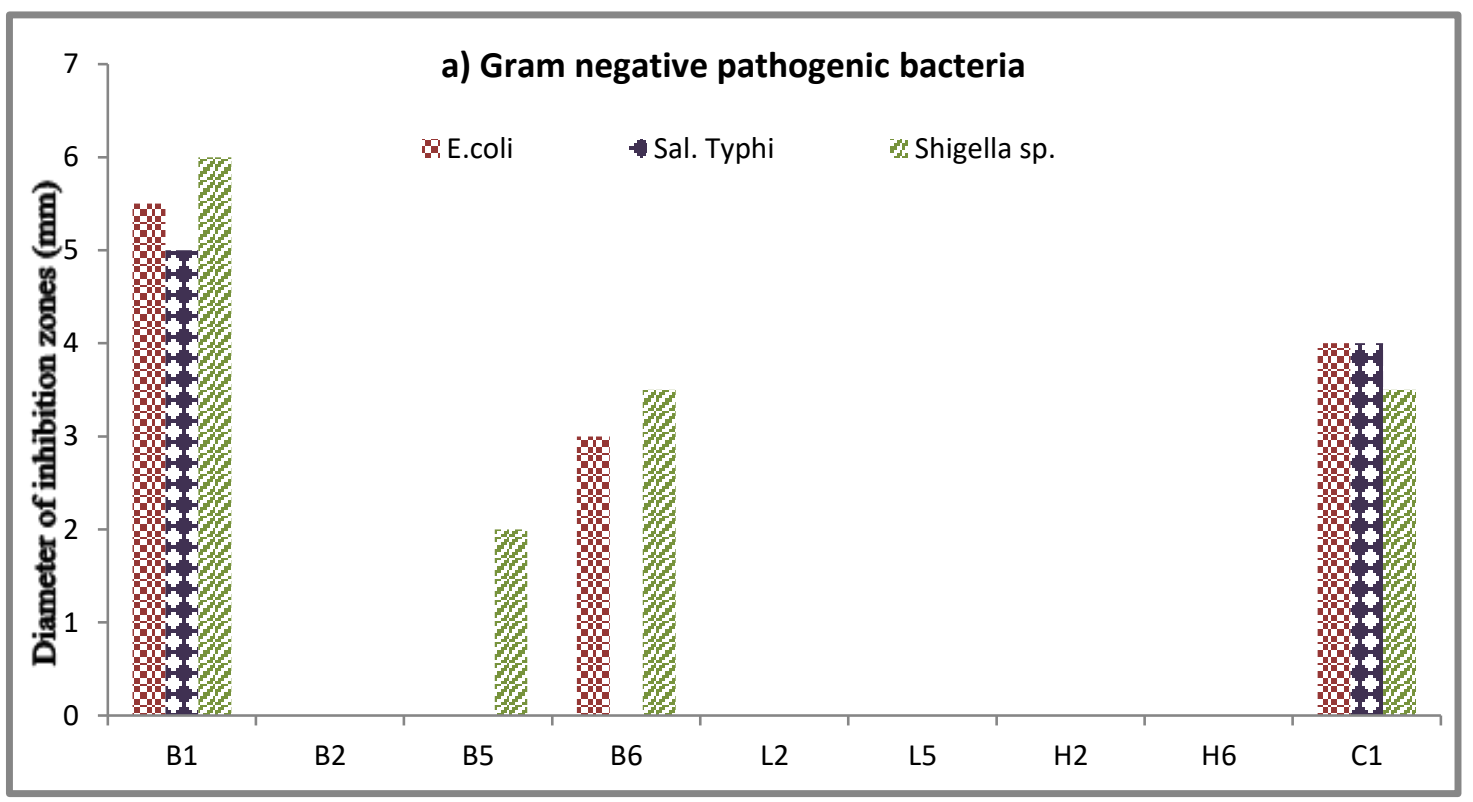

Fig 6. Antibacterial bioactivity (diameter of clear zone) of $L A B$ isolated from Luncheon (B), Pickles (L), Commercial sweeten yoghurt $(\mathrm{H})$ and White cheese $(\mathrm{C})$ against gram-negative pathogenic bacteria 


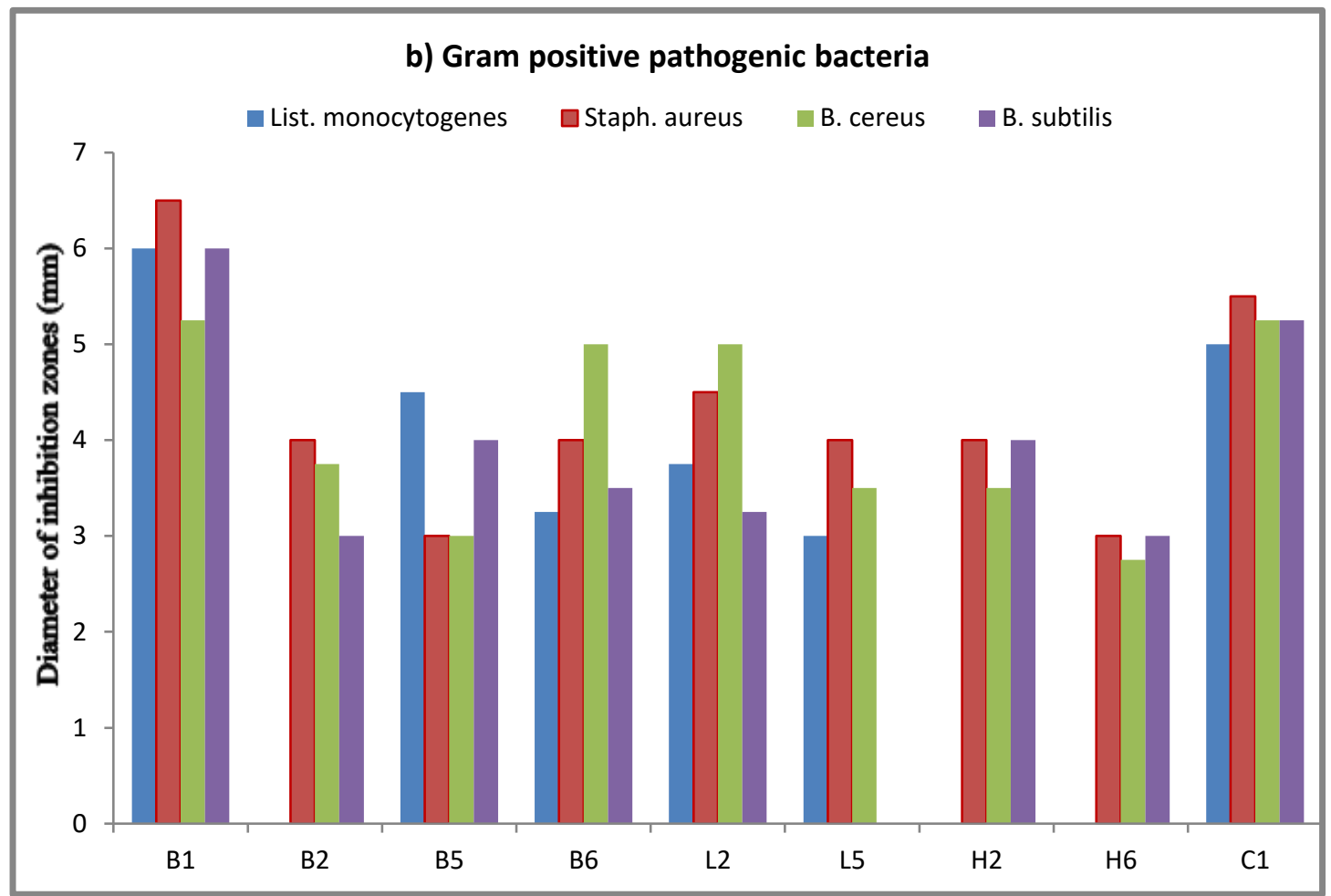

Fig 7. Antibacterial bioactivity (diameter of clear zone) of $L A B$ isolated from Luncheon (B), Pickles (L), Commercial sweeten yoghurt $(\mathrm{H})$ and White cheese $(\mathrm{C})$ against gram-positive pathogenic bacteria.

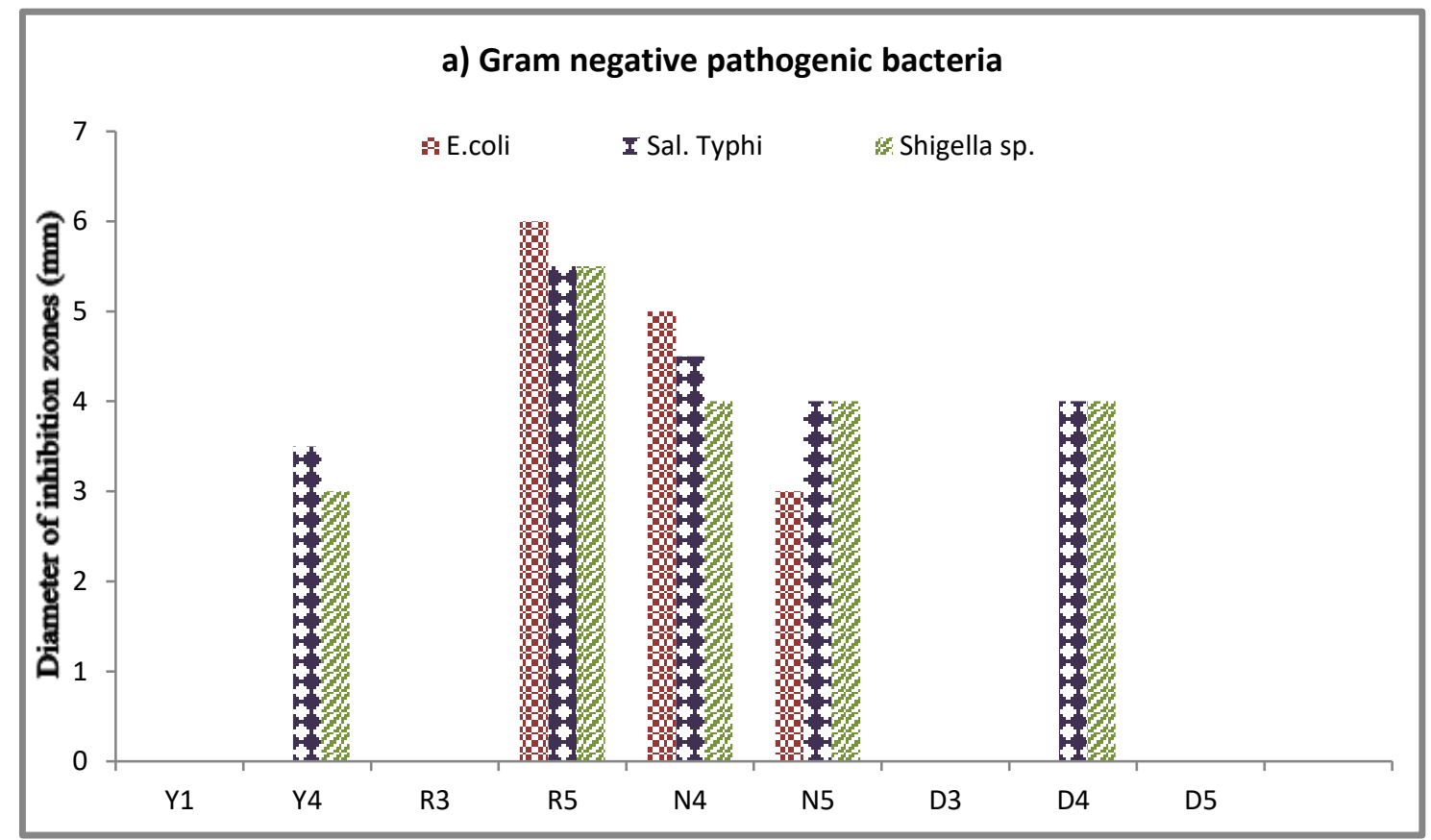

Fig 8. Antibacterial bioactivity (diameter of clear zone) of $L A B$ isolated from Local yoghurt (Y), Commercial yoghurt $(R)$, processed cheese $(N)$ and Fresh cheese $(D)$ against gram-negative pathogenic bacteria 


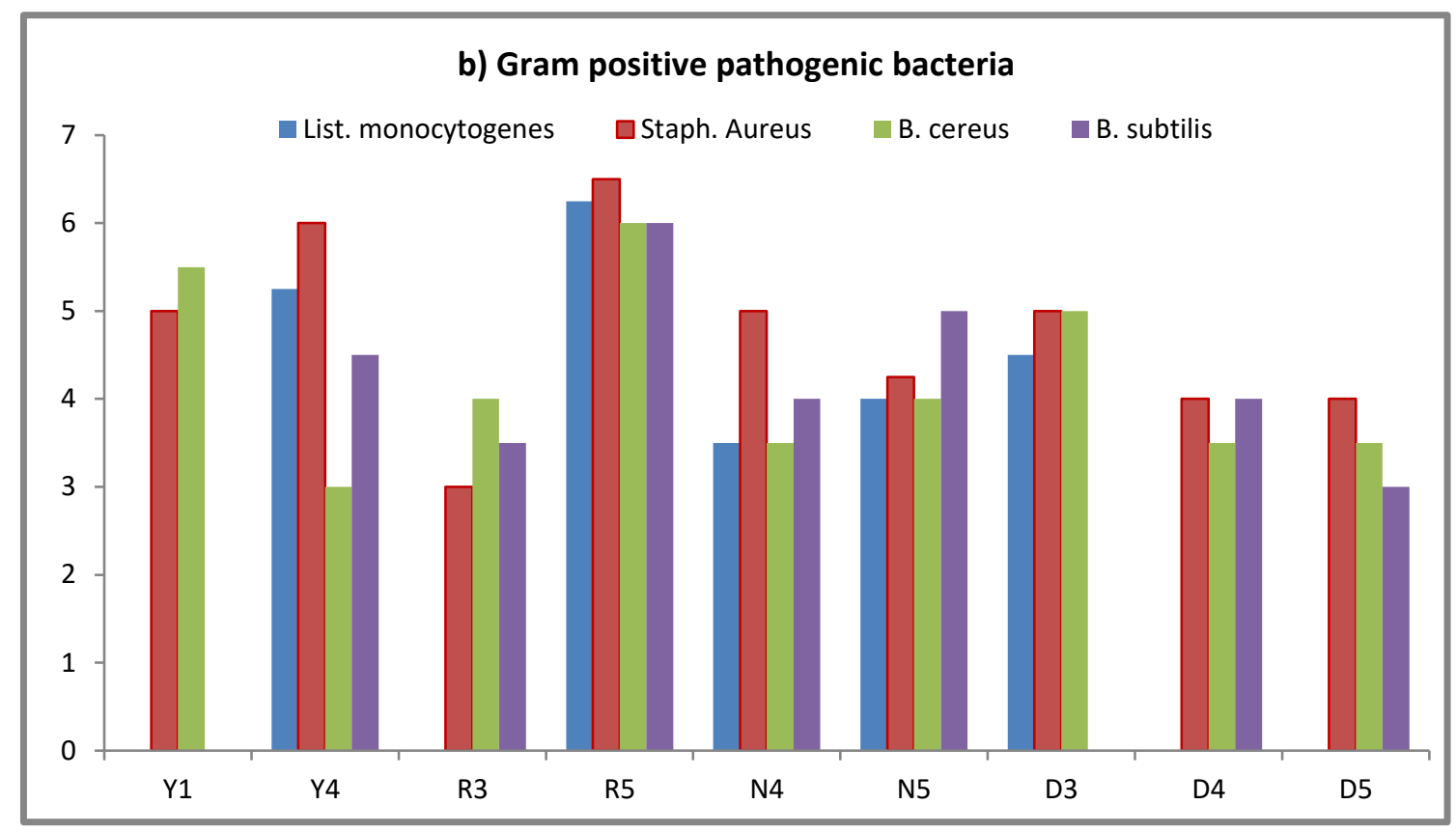

Fig 9. Antibacterial bioactivity (diameter of clear zone) of LAB isolated from Local yoghurt (Y), Commercial yoghurt $(R)$, processed cheese $(N)$ and Fresh cheese $(D)$ against gram-positive pathogenic bacteria

\section{Conclusion}

The current investigation showed that, some Lactic acid bacteria isolates, isolated from various Egyptian foods had antibacterial bioactive potential against some gram-negative and gram-positive food borne pathogen and spoilage microorganisms. Results showed that Lactobacillus rhamnosus strain, R5 isolate (isolated from Commercial yogurt) and S6 isolate (isolated from sour milk) had high active antibacterial bacteriocins. Therefore, it is recommended to further identify these isolated and do more experiments to investigate utilizing them or their bacteriocins in food product and probiotic bacteria.

\section{References}

Al-Zahrani, SH; Al-Zahrani, FS (2006) Production of bacteriocin(s) by four lactic acid bacteria isolated from raw milk on organic waste. World Applied Sci J 1, 135-143.

Belicova, A; Mikulasova, M; Dusinsky, R (2013) Probiotic potential and safety properties of Lactobacillus plantarum from Slovak bryndza cheese. BioMed Research International.
Danial, Enas N; Al-Zahrani, SHM; Zahra Al-HM; AlMahmoudi (2016) Enhancement of novel extracellular bacteriocin production by media optimization using LAB isolate from meat. $J$ of Applied Pharmaceutical Sci 6, 020-027.

Dhewa, T (2012) Screening, production purification and potential use of bacteriocins from lactic acid bacteria of meat and dairy food origin. International Conference on Nutrition and Food Sci 39, 35-41.

Fahim, HA; Khairalla, AS; El-Gendy, AO (2016) Nanotechnology: a valuable strategy to improve bacteriocin formulations: A Review. Frontiers in Microbiology 7, 1385.

Gautam, N; Sharma, N (2009) Purification and characterization of bacteriocin produced by strain of Lactobacillus brevis MTCC 7539. Indian J of Biochemistry and Biophysics 46, 337-341.

Guilhelmelli, F; Vilela, N; Albuquerque, P; da S. Derengowski, L; Silva-Pereira, I; Kyaw, CM (2013) Antibiotic development challenges: the various mechanisms of action of antimicrobial peptides and of bacterial resistance. Frontiers in Microbiology 4, $1-12$. 
Güllüce, M; Karadayi, M; Baris, Ö (2013) Bacteriocins: Promising antimicrobials. Microbial pathogens and strategies for combating them. In Science, Technology and Education; Mendes-Vilas, A., Ed.; FORMATEX: Madrid, Spain, pp 1016-1027.

Jeevaratnam, K; Jamuna, M; Bawa, AS (2005) Biological preservation of foods-Bacteriocins of lactic acid bacteria. Indian J Biotechnol 4, 446-454.

Khalil, I; Anwar, N (2016). Isolation, identification and characterization of lactic acid bacteria from milk and yoghurts. $J$ of Food and Dairy Technology 4, 17-26.

Kleanthous, C (2010) Swimming against the tide: progress and challenges in our understanding of colicin translocation. Nature Reviews Microbiology 8, 843-848. doi: 10.1038/nrmicro2454.

Mahantesh, M; Patil, APTA; Ramana, KV (2010) Isolation and characterization of lactic acid bacteria from curd and cucumber. Indian $J$ of Biotechnology 9, 166-172.

Mills, S; Serrano, L; Griffin, C; O'connor, PM; Schaad, G; Bruining, C (2011) Inhibitory activity of Lactobacillus plantarum LMG P-26358 against Listeria innocua when used as an adjunct starter in the manufacture of cheese. Microbial Cell Factories 10, S7. doi: 10.1186/1475-2859-10-S1-S7

Mirnejad, R; Vahdati, AR; Erfani, M; Piranfar, V (2013) The antimicrobial effect of Lactobacillus casei culture supernatant against multiple drug resistant clinical isolates of Shigella sonnei and Shigella flexneri in vitro. Iranian Red Crescent Medical J 15, 122-126. doi:10.5812/ircmj. 7454.

Mohammed, Wafaa F; Khalil, KMA; Hala M Abu Shady; Hayam A El-nabi Sayed (2016). Activity rang determination and optimization of various environmental conditions for bacteriocin production by Lactobacillus acidophilus and Lactobacillus plantarum. The Egyptian Society of Experimental Biology $12,53-66$.

Mokoena, MP; Mutanda, T; Olaniran, AO (2016) Perspectives on the probiotic potential of lactic acid bacteria from African traditional fermented foods beverages: A Review. Food Nutrition Research 60: 29630.

Murua, A; Todorov, SD; Vieira, ADS; Martinez, RCR; Cenci, A; Franco, BDGM (2013) Isolation and identification of bacteriocinogenic strain of Lactobacillus plantarum with potential beneficial properties from donkey milk. Journal of Applied Microbiology 14, 1793-1809. doi:10.1111/jam.12190.
Nallala, V; Sadishkumar, V; Jeevaratnam, V. (2016) Molecular characterization of antimicrobial Lactobacillus isolates and evaluation of their probiotic characteristics in vitro for use in poultry. Food Biotechnology 31, 20-41.

Nath, S; Chowdhury, S; Bora, KC; Sarkar, S (2014) Role of biopreservation in improving food safety and storage. $J$ of Engineering Research and Applications 4, 26-32.

Nikita, C; Hemangi, D (2012) Isolation, Identification and characterization of lactic acid bacteria from dairy sludge samples. $J$ of Environmental Research and Development 7, 234-244.

Parada, JL; Caron, CR; Medeiros, ABP; Soccol, CR (2007) Bacteriocins from lactic acid bacteria: Purification, Properties and use as biopreservatives. Brazilian Archives of Biology and Technology 50, 521542.

Puniya, M; Sangu, KPS; Bhardwaj, A; Gupta, D; Kumar, S; Dhewa, T; Plant, S (2012) Probiotic and Functional attributes of Lactobacillus Spp isolated from human feces. $J$ of Research in Antimicrobials 1, 001-011.

Quinto, EJ; Jiménez, P; Caro, I; Tejero, J; Mateo, J; Girbés, T (2014) Probiotic lactic acid bacteria: A review. Food and Nutrition Sci 5, 1765-1775.

Rashmi, D; Srinivas, S; Sharmila, T (2017) Study of Antagonistic Properties of Bacteria from Cow's Milk by Real Time Surface Plasma Resonance Biosensor (BIAcore). $J$ of Pharmaceutical Chemical and Biological Sci 5, 365-370.

Sadishkumar, V; Jeevaratnam, K (2016) In vitro probiotic evaluation of potential antioxidant Lactic acid bacteria isolated from Idli batter fermented with Piper betel leaves. International Journal of Food Science and Technology 52, 329-340.

Sangita, B; Apoorva, S; Manisha, M; Sharma, SK (2013) Isolation and Characterization of Lactic Acid Bacteria from Fermented Foods. International $J$ of Plant Research 26, 325-330. doi: 10.5958/j.22294473.26.2.092.

Savadogo, A; Cheik, ATO; Imael, HNB; Traore, AS (2004) Antimicrobial activity of lactic acid bacteria strains isolated from Burkina Faso fermented milk. Pakistan J Nutrition 3, 174-179.

Settanni, L; Aldo, C (2008) Application of bacteriocins in vegetable food biopreservation. International $J$ of Food Microbiology 121, 123-138. 
Isolated from Various Egyptian Products

Simova, ED; Beshkova, DB; Dimitorv, ZHP (2009) Characterization and antimicrobial spectrum of bacteriocins produced by lactic acid bacteria isolated from traditional Bulgarian dairy products. Journal of Applied Microbiology 106, 692-701.

Snyder, AB; Worobo, RW (2013) Chemical and genetic characterization of bacteriocins: antimicrobial peptides for food safety: A Review. J of the Science of Food and Agriculture 94, 28-44. doi: $10.1002 /$ jsfa.6293
Somashekaraiah, R; Shruthi, B; Deepthi, BV; Sreenivasa, MY (2019) Probiotic Properties of Lactic Acid Bacteria Isolated from Neera: Naturally Fermenting Coconut Palm Nectar. Frontiers in Microbiology 10, 1382.doi: 10.3389/fmicb.2019.01382

Zacharof, MP; Lovitt, RW (2012) Bacteriocins produced by lactic acid bacteria: A Review Article. APCBEE Procedia 2, 50-56. 


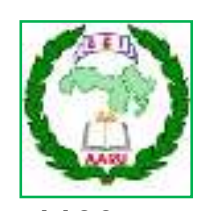

مجلة اتحاد الجامعات العربية للعلوم الزراعية، جامعة عين شمس، القاهرة، مصر مجلد(28)، عدد(4)،

النشاط الحيوى المضاد للبكتريا لبعض بكتريا حمض اللاكتيك المعزولة

\section{من منتجات مصرية متنوعة}

$$
\begin{aligned}
& \text { أمير محب كامل1" - أزهار عبدالفتاح السيد²- بثينة محمد يوسف1 - شيماء عبدالرؤوف أمين2 }
\end{aligned}
$$

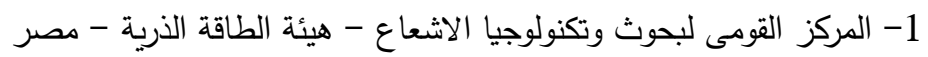

$$
\begin{aligned}
& \text { 2- قسم الميكروبيولوجيا الزراعية-كلية الزراعة - جامعة عين شمس - ص.ب لب } 68 \text { - حدائق شبرا } 11241 \text { - القاهرة - مصر }
\end{aligned}
$$

*Corresponding author: AmirKamel2005@yahoo.com

Accepted 19 November, 2020

المعامله بالبكتريوسين المنقى جزئياً وظهور هالات

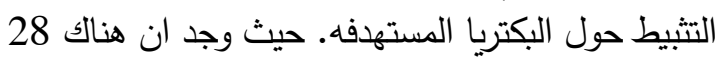

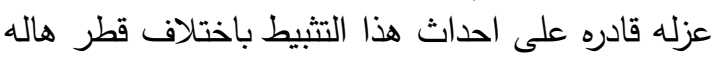
التتبيط والتى تدل على مدى التى حساسيه السلاله المستهدفه

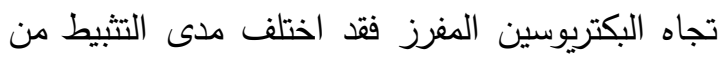
ضعيف الى قوى وكذللك اختلف تجاه البكتريا الموجبه البناه

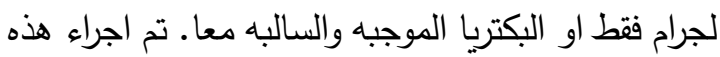

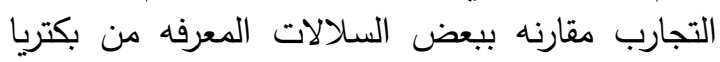

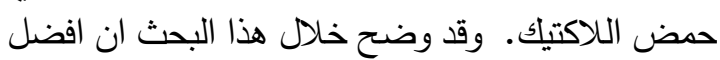

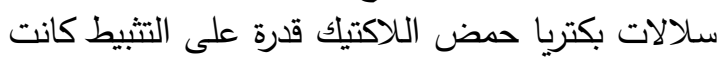

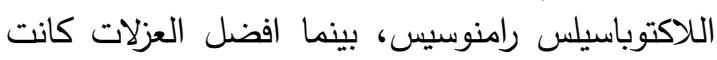

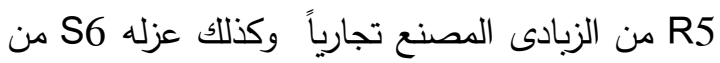
اللبن الرايب المصنع تجاريا.

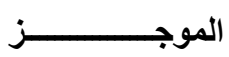

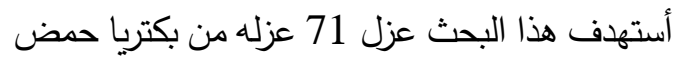

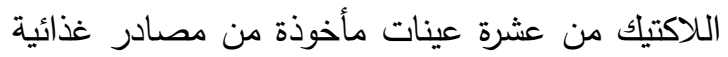

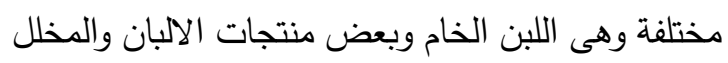

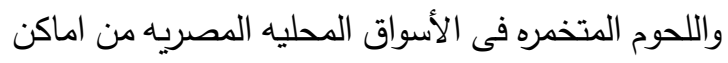

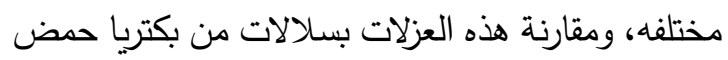

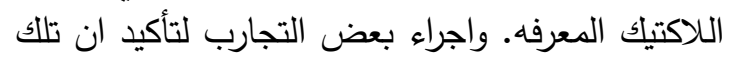

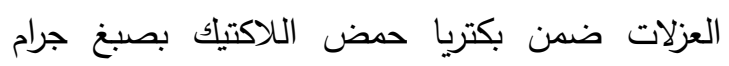

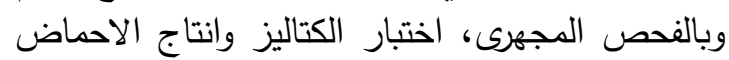

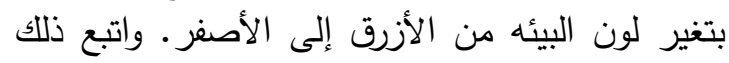

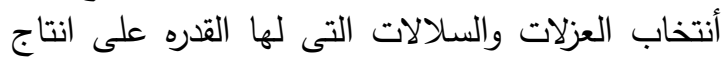

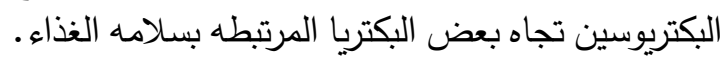

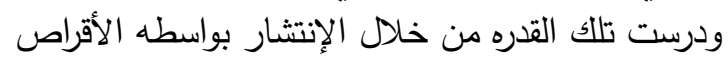

